\title{
Effects of Climate Variabilityon Cocoa Production in Ondo State, Nigeria
}

\author{
Omosuyi Oluwayemisi Bukola, Akinfisoye Emmanuel Oluwadunsin, \\ Funmilayo Olukemi Abimbola \\ Department of Geography, Adeyemi College of Education, Ondo, Nigeria \\ Email: yemipaul2004@yahoo.com, akinfisoyee@aceondo.edu.ng, funmilayooa@aceondo.edu.ng
}

How to cite this paper: Bukola, O. O., Oluwadunsin, A. E., \& Abimbola, F. O. (2021). Effects of Climate Variabilityon Cocoa Production in Ondo State, Nigeria. American Journal of Climate Change, 10, 396-406. https://doi.org/10.4236/ajcc.2021.104020

Received: August 23, 2021

Accepted: November 26, 2021

Published: November 29, 2021

Copyright $\odot 2021$ by author(s) and Scientific Research Publishing Inc. This work is licensed under the Creative Commons Attribution International License (CC BY 4.0).

http://creativecommons.org/licenses/by/4.0/

\begin{abstract}
There is an increasing awareness that the climate is changing and its changing impact has been significant on agricultural produce. This change is posing a major threat to agricultural development in Nigeria. Cocoa cultivation is one of the major cash crops in Ondo state and also a major agricultural produce which contributes significantly to employment generation and foreign exchange in the country. It has been observed that the production of cocoa over the years has been marked with fluctuations which could be attributed to the change in climate over the years. The objectives of this study include: examining the variation in the trend of cocoa production; and assessing the effects of climate variability on cocoa production for the year under review. This study made use of secondary data which included data on climatic variables (mean annual temperature, mean annual rainfall and mean annual humidity) and cocoa output from 1976-2020. This study employed mainly inferential statistics for data analysis-trend analysis, correlation and regression. Trend analysis was used to examine climatic variables and cocoa production. The correlation analysis was used to show the relationship between the climatic variables and the cocoa yield. Also, regression analysis was used to evaluate the effect of the climatic variables on cocoa production. Trend analysis reveals fluctuations in climatic variables and cocoa output over the years of study. Correlation analysis shows an inverse relationship between rainfall and cocoa output while regression analysis shows that humidity and temperature are expected to increase cocoa output. For a sustainable cocoa production, it is recommended that both governmental and non-governmental organizations should employ more extension agents to guide and enlighten cocoa farmers on climate change, its effects and the appropriate coping strategies.
\end{abstract}

\section{Keywords}

Climate Variability, Cocoa, Humidity, Rainfall, Temperature 


\section{Introduction}

The United Nation Framework Convention on Climate Change (UNFCCC) defines climate change as a change of climate which is attributed directly or indirectly to human activities that alter the composition of the global atmosphere and which are in addition to natural climate variability, observed over comparable time periods. On the other hand the Intergovernmental Panel on Climate Change (IPCC) defines climate change as a statistically significant variation in either the mean state of the climate or in its variability, persisting for an extended period (typically decades) (IPCC Working Group I, 2001). Climate change is a major challenge facing the global environment now and it is arguably the most threatening environmental problem of our time. Climate change effect is more pronounced in Africa because of its location, its sole dependence on agriculture and its generalized incapacity to cope and adapt to climate extreme (FAO, 2003; Bolaji-Olatunji et al., 2010). The adverse effect of climate change continues to be a major threat to rural livelihoods (Pouliotte et al., 2009). It imposes constraints to development especially among small holder farmers whose livelihoods mostly depend on rain-fed agriculture (IPCC, 2007; Tanner \& Mitchell, 2008). In Nigeria, increased agricultural production is very essential for rural poverty alleviation. However, climate change is notable among the major constraints that are to be addressed. Medugu (2009) indicated that recently, persistent drought, flooding, off-season rain and dry spells have disrupted crop growing seasons in many Nigeria agro-ecological zones. This means that any change in climate will definitely affect agricultural practices in Nigeria since agriculture in Nigeria is mostly rain-fed. The impact could, however be measured in terms of effects on crop growth, availability of soil water, soil erosion, incidence of pest and diseases and decrease in soil fertility (Adejuwon, 2004). However, findings by Odjugo (2010) revealed that since 1901 trend of temperature in Nigeria shows increasing pattern. This increase was gradual until late 1960s and this gave way to a sharp rise in air temperature from the early 1970s which continued till date. Likewise rainfall trend between 1901 and 2005 shows a general decline. Within 105 years, rainfall amount in Nigeria dropped by $81 \mathrm{~mm}$. The declining rainfall became worst from the early 1970s and the pattern has continued to date. This period of drastic rainfall decline corresponds with the period of sharp temperature rise. Although there is a general decrease in rainfall in Nigeria, the coastal areas of Nigeria are observed to be experiencing slightly increasing rainfall in recent times. This is a clear evidence of climate change because a notable impact is increasing rainfall in most coastal areas and decreasing rains in the continental interiors (NEST, 2003). Odjugo (2010) observed that the number of rain days dropped by $53 \%$ in the north-eastern Nigeria and $14 \%$ in the Niger-Delta coastal areas. Nigeria Meteorological Agency (NIMET, 2011) noted that in August 2010, some places in the Southwest including Ondo state recorded rainfall values that were $200 \%$ - $300 \%$ higher than normal and is the largest cocoa producer in 
Nigeria; it has records of fluctuations in some climatic parameters, especially rainfall, temperature and sunshine hours. Therefore, understanding the effect of climate change on cocoa production is needed to cope with the expected changes in climatic parameters most especially temperature, rainfall and relative humidity.

Agricultural practice is one of the most important primary activities of people as a means of livelihood and development. Indeed, it is the bedrock of every economic development and it is doubtful to attain a meaningful level of economic progress without developing the agricultural sector. Of all agricultural produce in Nigeria, cocoa is the leading non-oil foreign exchange earner but dominance of smallholders and inadequate farm labour due to urbanization and climate variability hold back production.

Cocoa production in Nigeria is one of the major agricultural products which contribute significantly to employment generation and foreign exchange for the country. The main producing states are Ondo, Ekiti, Oyo, Osun, Ogun, Delta, Edo, Cross Rivers and Akwa Ibom. Since the introduction of cocoa to Nigeria, it has grown to become a major export crop (Oyedele, 2007). Wilcox and Abbot (2004) identified Nigeria as the third largest cocoa producing country in Africa producing about $12 \%$ of the total world production behind Ivory Coast and Ghana that produces $35 \%$ and $13 \%$ respectively. Presently, Nigeria's capacity of cocoa production has grown to about 385,000 metric tons per annum, a significant increment of 215,000 metric tons from year 2000 production level. This put Nigeria fourth among the highest cocoa producing nations in the world behind Ivory Coast, Indonesia and Ghana (Erelu, 2008).

Cocoa plant is highly sensitive to changes in climatic factors such as sunshine hour, rainfall, soil, air and temperature. Stages of development of pests and pathogens are influenced by climate change and this affects cocoa yields. Cocoa seedling mortality is encouraged by drought, in like manner, water deficit in cocoa plant results in low yield and increase in the level of capsid damage. Cocoa is known to produce well with minimal but sustained water availability throughout the year (Obatolu et al., 2003). Blackpod diseases account for quite a lot of cocoa production losses by attacking the ripened or very young pods. This is mostly prevalent during wet season and in damp situations.

Agricultural practice in Ondo state is rain-fed and solely dependent on climatic variables. However, cocoa yield in the state is determined by the rainfall variability, since agricultural production in part of the tropic is rain-fed, and recognizing that the constraints of rain-fed agriculture in Nigeria is as a result of erratic rain distribution (Jonathan et al., 2009). A number of factors have interrelated impacts on the growth of cocoa plant. These factors range from weather elements of rainfall, temperature, sunlight and humidity to others such as soil nutrient status, pest and diseases, farmers planting practices and so on. In this regard, this study examines the effect of climate change on cocoa production in Ondo state. The specific objectives are to: 
1) examine the variation in the trend of cocoa production from 1976-2020;

2) determine the effects of climatic trend on cocoa production for the same period as indicated above.

\section{Materials and Method}

\subsection{Study Area (Figure 1)}

Ondo state was created on the 3rd of February, 1976 and it is made up of 18 Local Government Areas. The state lies between Longitude $4^{\circ} 30^{\prime \prime}$ and $6^{\circ}$ East of the GMT, and Latitude $5^{\circ} 45^{\prime \prime} \mathrm{N}$ and $8^{\circ} 15^{\prime \prime} \mathrm{N}$ of the Equator. It has land area of 15,500 $\mathrm{km}^{2}$. It is located in the Southwestern part of Nigeria. The climate of the state is of the tropical rainforest type, characterized by distinctive wet and dry seasons, mean annual temperature of $27^{\circ} \mathrm{C}$ and mean annual rainfall of $2000 \mathrm{~mm}$ associated with relative humidity of not less than $70 \%$. The natural vegetation is typical of the high forest composed of many varieties of hard timber such as Milicia excels (iroko), Terminaliaivorensis (black afra), Heveabrasiliensis (rubber), etc. Over most part of the state, the natural vegetation has been very much degraded due to human activites. Tree crops cultivated in the study area include cocoa, kola, coffee, rubber, oil palm and citrus while food crops include cassava, yam, maize, plantain, cocoyam, okro and vegetables. Large proportion of the population of the study area engages mainly in agriculture with few in the public service employment.

\subsection{Source of Data}

Secondary data was used mainly for this study. Data on climatic variables were collected from the Agro-Climatological Department, Ondo state Ministry of Agriculture, Fisheries and Forest Resources, Akure. Also data on Cocoa output was obtained from the Department of Produce Services, Ondo state Ministry of Natural Resources, Akure.

\subsection{Method of Data Analysis}

Inferential statistics was employed mainly for this work. Trend analysis was used to examine the trends of climatic variables and cocoa output from 1976-2016. Regression analysis was used to estimate the effect of these climatic variables on Cocoa output.

\section{Results of Findings and Discussion}

\subsection{Trend Analysis of Some Climatic Variables in the Study Area from 1976-2016}

The mean annual record of temperature of Ondo state in Figure 2 reported the trend of mean annual temperature from 1976-2020.

The analysis above showed a slight increase from year 1976 to 1979 and a sudden drop in 1980. A stable temperature trend was experienced between years 1981 and 1985 but declined in year 1986. The mean annual temperature pattern 


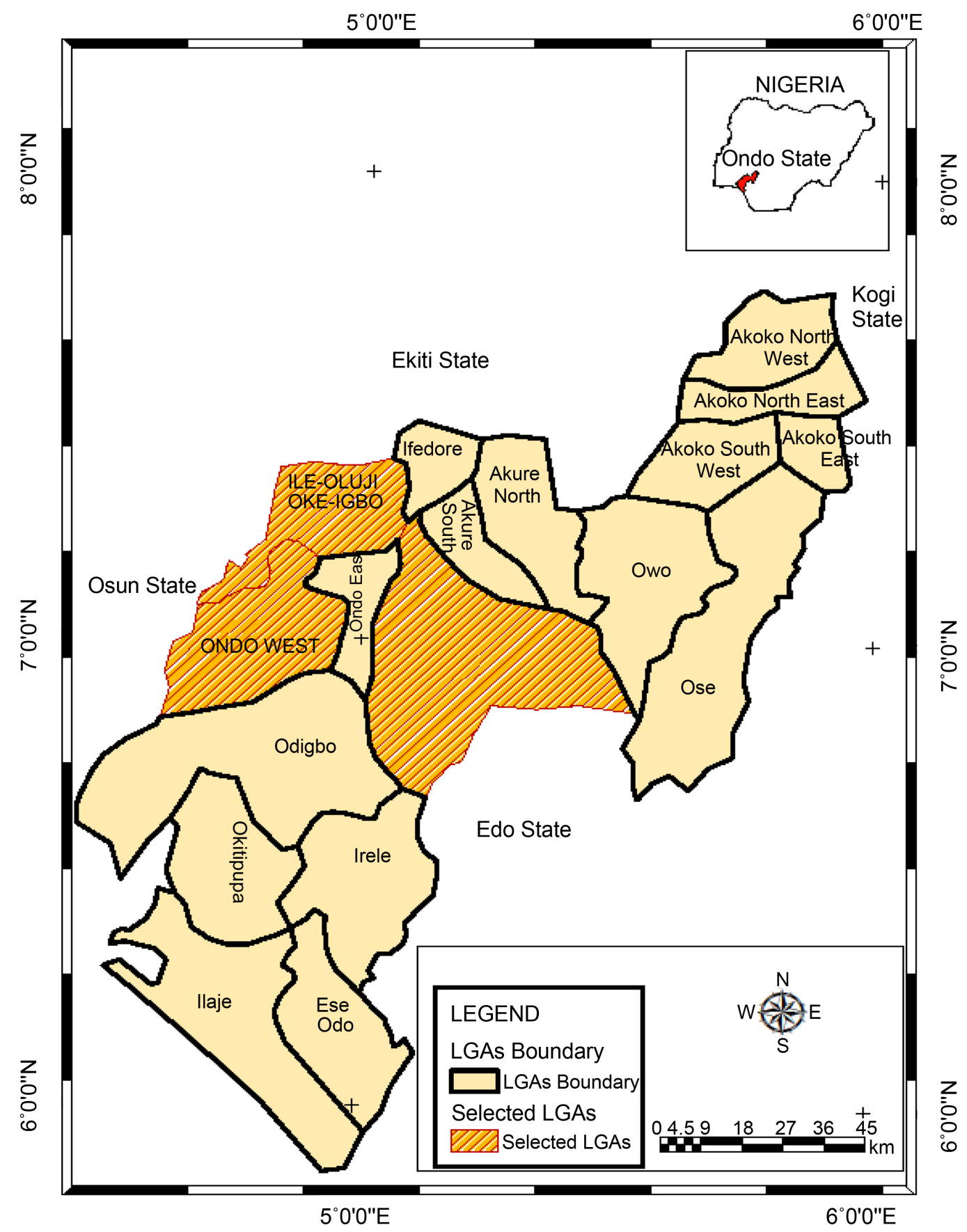

Figure 1. Map of Ondo State showing the three largest cocoa producing LGAs. Source: Modified after ministry of natural resources, Ondo State, Akure (2021).

fluctuated with the year 2001 recording the lowest value of $21.52^{\circ} \mathrm{C}$. Also there was a sharp rise in $2014\left(29.93^{\circ} \mathrm{C}\right)$ which marked the highest mean annual temperature ever recorded in the study area. However, the decrease in the mean temperature of the year 2020 could be as a result of the coronavirus pandemic where there were no or lesser industrial activities as well little or no vehicular movement due to the lockdown.

The trend of mean annual rainfall from 1976 to 2020 in Ondo State is reflected 


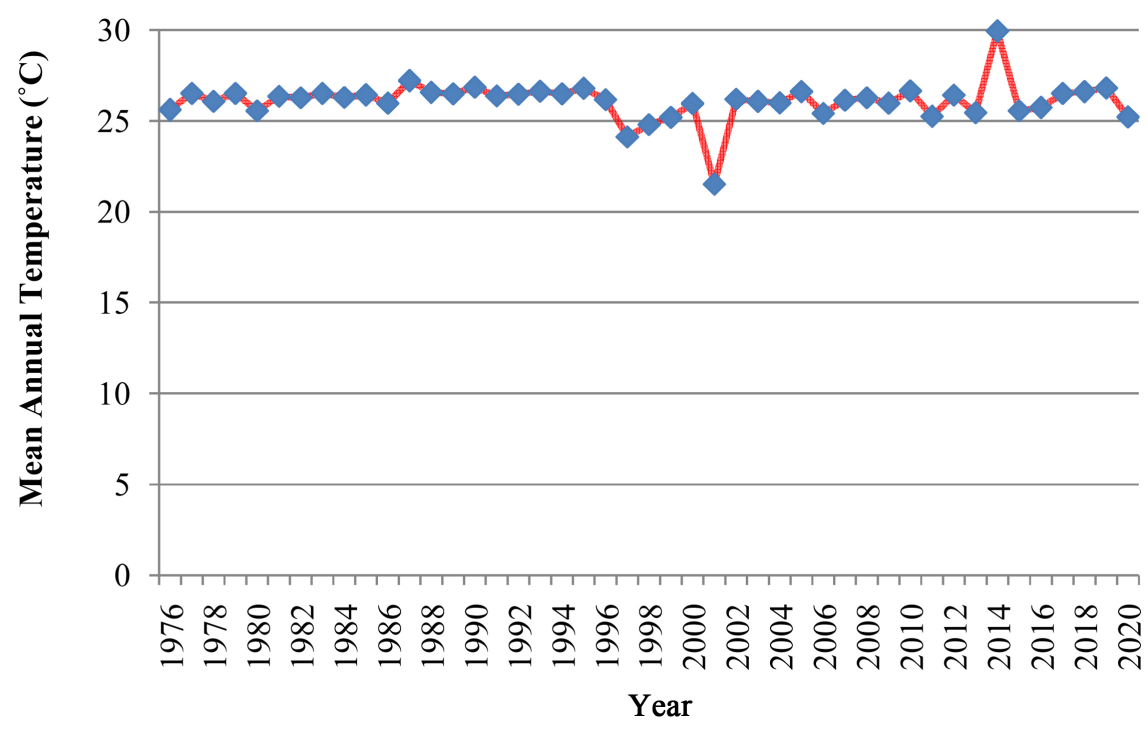

Figure 2. Trend of temperature in the study area. Source: Authors' compilation (2021).

in Figure 3. Rainfall pattern fluctuated throughout the study period. It showed an increasing trend from year 1976 to 1978 then dropped in 1979 while on a decrease from 1981 to 1984 . The highest mean annual rainfall of $2542.30 \mathrm{~mm}$ was recorded in the year 1985. The lowest mean annual rainfall was recorded in the year $1983(1257.30 \mathrm{~mm})$.

The mean annual relative humidity of the study area as shown in Figure 4 reflects a decreasing trend from the year 1979 to 1985 and relatively stable between 1986 and 1989. The figure also showed dwindling and fluctuating occurrences along the year path with year 2008 recording the lowest (70.13\%) while 1979 had the highest mean annual relatively humidity (86.08\%).

The fluctuations in these climatic variables could be said to be caused by the changes in the atmospheric constituents. This is related to the amount of particulate matters (aerosols) present in the atmosphere as well as carbon dioxide, water vapour and variation in ozone layer. Atmospheric constituents have a significant role in the energy budget of the earth through regulating energy exchange between the earth and the sun (Matsui \& Pielke Sr., 2006; Knorr, 2009). Also these fluctuations could be attributed to changes in the vegetal cover of the earth. Vegetal surfaces have different albedo compared to the bare surfaces, changes in the vegetal cover of the earth surface means changing the amount of energy recipient on the earth.

\subsection{Trend of Cocoa Production in the Study Area}

The trend in cocoa production in Ondo state between 1976 and 2020 is shown in Figure 5. Cocoa production in the study area showed a fluctuating pattern throughout the years under review. It showed an increasing trend from 1976 to 1978 but dropped in 1979. Also, it showed an increasing trend from 1986 to 1988. Cocoa output was on a decrease from 1993 to 1998. In the year 1988 the 


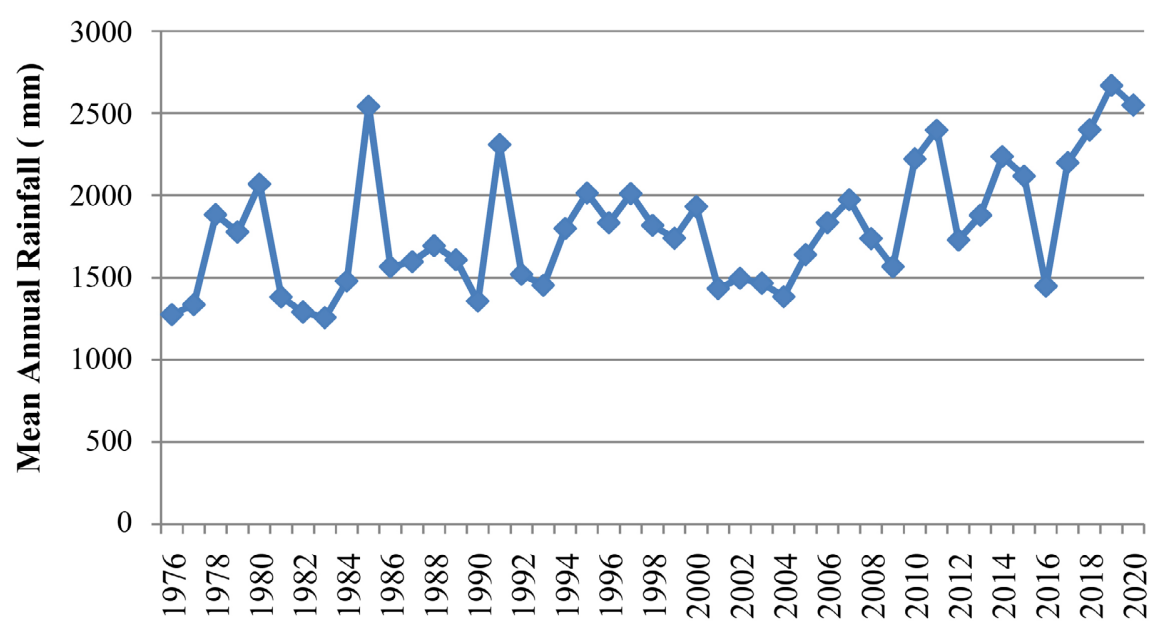

Year

Figure 3. Trend of rainfall in the study area. Source: Authors' compilation (2021).

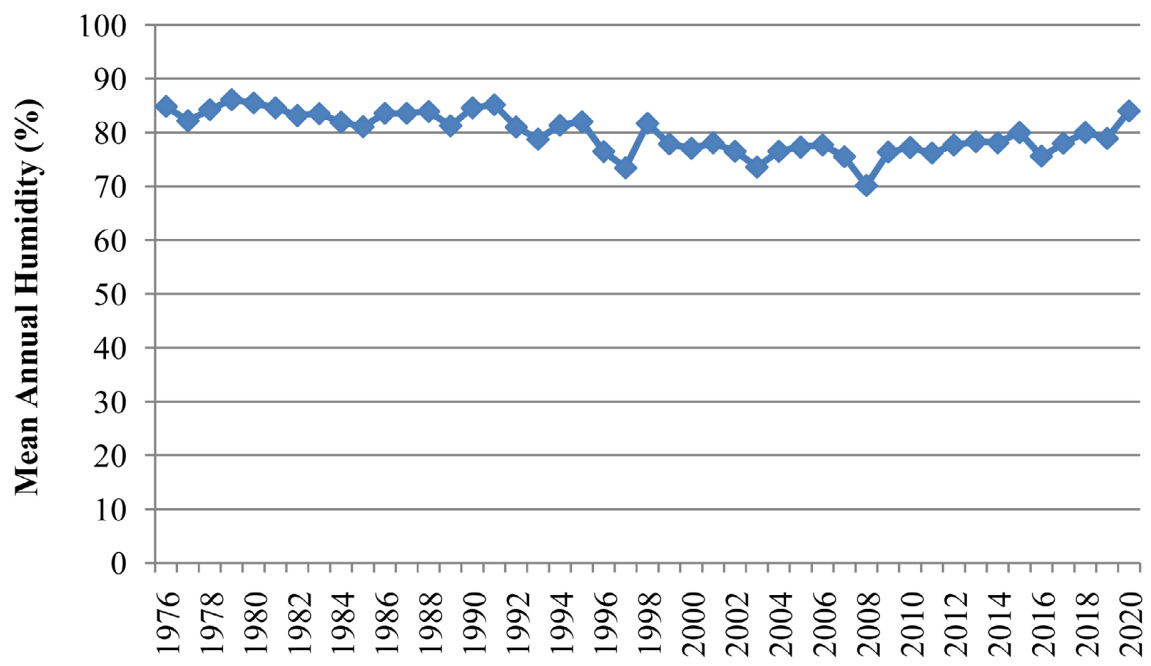

Year

Figure 4. Trend of relative humidity in the study area. Source: Authors' compilation (2021).

study area recorded highest cocoa production of 110,457 MT, higher than any other year. Year 2000 recorded the lowest production of 24,027 MT. The figure equally showed a dwindling and fluctuating occurrences along the production path from year 2001 to year 2016. Fluctuation in cocoa production witnessed could be as a result of the fluctuations recorded in the climatic variables.

\subsection{Relationship between Climatic Elements and Cocoa Output}

Correlation and multiple regression analysis were conducted to examine the relationship between Cocoa output and some selected weather variables-rainfall, temperature and humidity in the study area. Table 1 shows the degree of relationship between Cocoa output in Ondo State and climatic variables. It reveals 


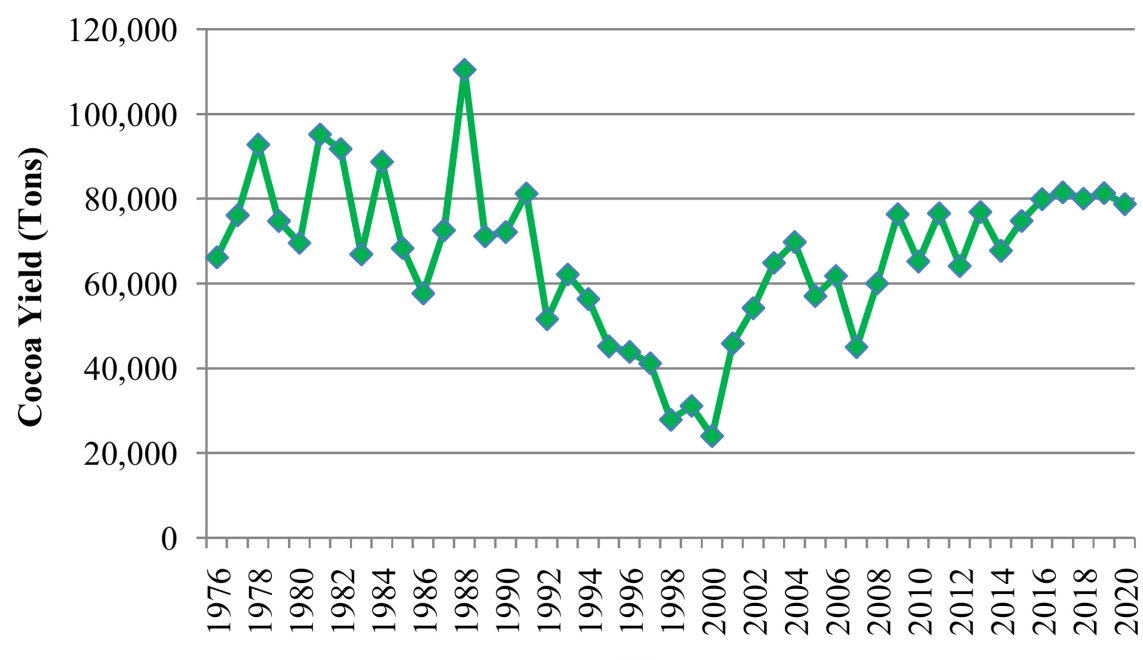

Year

Figure 5. Trend of cocoa production in the study area. Source: Author's compilation (2021).

Table 1. Relationship between the cocoa yield and climatic variables.

\begin{tabular}{ccccc}
\hline \multirow{2}{*}{$\begin{array}{c}\text { Dependent } \\
\text { Variables }\end{array}$} & Pearson & \multicolumn{3}{c}{ Independent Variables } \\
\cline { 3 - 5 } & Correlation & Temperature & Rainfall & Humidity \\
\hline \multirow{2}{*}{ Cocoa } & Value & .309 & -.139 & .414 \\
& Sig (2tailed) & .049 & .387 & .007 \\
& Number & 45 & 45 & 45 \\
\hline
\end{tabular}

that there is a weak linear relationship between temperature and Cocoa output. $\mathrm{r}(39)=.31, p<.01$. Similarly humidity and Cocoa outputs were correlated. $\mathrm{r}(39)=.41, p<.01$. This means that as temperature and humidity increase, cocoa output tend to increase. These results are statistically significant.

This is in line with Adejuwon and Odekunle (2006) assertion that although cocoa plant will survive above $32^{\circ} \mathrm{C}$ since the upper temperature limit is not well defined and shade cover will influence maximum temperatures for the cocoa tree though high temperature may affect bean characteristics and yield. On the other hand, Table 1 showed an inverse relationship between rainfall and Cocoa outputs in the study area. $\mathrm{r}(39)=-.14, \mathrm{p}=.387$. It can further be observed that the inverse relationship between Cocoa output and rainfall is not statistically significant. This means that the effect of rainfall on cocoa production is minimal. This may be as a result of different chemicals used by cocoa farmers to improve cocoa yield as a substitute for insufficient rainfall.

From Table 2, the Adjusted $\mathrm{R}$ value is .181, while $\mathrm{R}^{2}$ value is .243. This means that the independents variables (Rainfall, Temperature and Humidity) contribute $24.3 \%$ to the variability of the dependent variable (Cocoa-output) between 1976 and 2020. This result is statistically significant, $(p=.015)$.

In addition, from Table 3, humidity had a significant regression weight of .352, $p$ $=.022$, while temperature had a non-significant regression weight of $.259, p=.085$. 
Table 2. The effect of climatic variables on cocoa output (regression).

\begin{tabular}{cccccc}
\hline Model & $\mathrm{R}$ & $\mathrm{R}^{2}$ & $\begin{array}{c}\text { Adjusted } \\
\mathrm{R}^{2}\end{array}$ & $\begin{array}{c}\text { Standard } \\
\text { Error of } \\
\text { Estimate }\end{array}$ & Durbin-Watson \\
\hline 1 & .493 & $24.3 \%$ & .181 & $16,528.14635$ & 1.404 \\
\hline
\end{tabular}

**Significant at $5 \%$.

Table 3. The significance level of each climatic variable on cocoa yield.

\begin{tabular}{|c|c|c|c|c|c|c|c|c|}
\hline & \multirow{2}{*}{ Model } & \multicolumn{2}{|c|}{$\begin{array}{c}\text { Unstandardized } \\
\text { Coefficients }\end{array}$} & \multirow{2}{*}{$\begin{array}{c}\text { Standardized } \\
\text { Coefficients } \\
\text { Beta }\end{array}$} & \multirow{2}{*}{$\mathrm{t}$} & \multirow{2}{*}{ Sig. } & \multicolumn{2}{|c|}{$\begin{array}{l}\text { Collinearity } \\
\text { Statistics }\end{array}$} \\
\hline & & B & $\begin{array}{l}\text { Std. } \\
\text { Error }\end{array}$ & & & & Tolerance & VIF \\
\hline \multirow{4}{*}{1} & (Constant) & $-166,259.034$ & $76,451.745$ & & -2.175 & .036 & & \\
\hline & Temp & 4227.727 & 2391.198 & .259 & 1.768 & .085 & .952 & 1.050 \\
\hline & Rain & -6.701 & 8.129 & -.120 & -.824 & .415 & .966 & 1.035 \\
\hline & Hum & 1666.141 & 695.474 & .352 & 2.396 & .022 & .946 & 1.057 \\
\hline
\end{tabular}

The implication of this is that high humidity and temperature are expected to increase Cocoa outputs in the study area. On the other hand, rainfall had a non-significant and regression weight of $-.824, p=.415$.

\section{Conclusion}

Climate change in this dispensation is a global phenomenon affecting every facet of life. The effect ranges from unpredictable climate to variation in weather elements. This is significantly affecting the economic strength of individual nation globally. However, there is an increasing awareness that the climate is changing and its changing impact has been significant on agricultural produce. This change is posing a major threat to agricultural development in Nigeria. Cocoa cultivation as one of the major cash crops in Ondo state and also a major agricultural produce which contributes significantly to employment generation and foreign exchange in the country has been observed with marked fluctuations which could be attributed to the change in climatic variables over the years.

In view of the above, the study however, concluded that the climate of Ondo state is not stable and this amongst other factors has brought about fluctuations in cocoa production in the study area for the last forty-five years (1976-2020). The study also revealed based on the result of the regression analysis that means annual temperature and mean annual relative humidity had a considerable effect on cocoa production with humidity being the most important factor.

\section{Recommendation}

Evidence shown in this research reveals the effect of climate change on cocoa production. Recommendations that stem from this finding include the following: 
- Government should ensure that fungicides for spraying cocoa tree to prevent incidence of black diseases are available to farmers at affordable prices.

- Both the governmental and non-governmental organizations should employ more extension agents to guide and enlighten cocoa farmers on the use of different cocoa tree chemicals and seed varieties that can cope with different climatic conditions.

- Accessible loans and credit facilities should be made available to cocoa farmers in order to purchase required chemicals and seed varieties needed to adapt to climatic variability.

- Also, research efforts should be made towards developing low cost dryers to dry cocoa beans mostly during rainy season. This could be achieved by revitalizing our research institutions.

- Cocoa farmers need to be educated on climate change, its causes and effects as well as the appropriate strategies to cope with it. This could be made realistic by the involvement of relevant stakeholders.

\section{Conflicts of Interest}

The authors declare no conflicts of interest regarding the publication of this paper.

\section{References}

Adejuwon, J. O., \& Odekunle, T. O. (2006). Variability and Severity of Little Dry Season in South Western Nigeria. Journal of Climate, 19, 483-493. https://doi.org/10.1175/JCLI3642.1

Adejuwon, S. A. (2004). Impact of Climate Variability and Climate Change on Crop Yield in Nigeria. Contributed paper to Stakeholders Workshop on Assessment of Impact and Adaptation to Climate Change (AIACC): 2-8.

Bolaji-Olatunji, K. A., Olufolaju, A. D., \& Awe, F. (2010). Climate Change, Adoption and Sustainability Natural Resources Management in Nigeria. In J. A. Akinlade, A. B. Ogunwale, \& V. O. Asaolu (Eds.), Proceedings of the 44th Annual Conference of Agricultural Society of Nigeria (ASN) (pp. 1449-1451). Agricultural Society of Nigeria.

Erelu, O. O. (2008). Cocoa for Health and Wealth. A Paper Presented in a Fourth Cocoa Day Celebration in Osun State, Nigeriabetween, 22nd-24th April 2008, 1-12.

Food and Agricultural Organization of the United Nations (FAO) (2003). FAOSTAT. https://www.fao.org/faostat/en/\#home

IPCC (Intergovernmental Panel on Climate Change) (2001). Climate Change 2001: Impacts, Adaptation and Vulnerability. Third Assessment Report. Cambridge University Press.

IPCC (Intergovernmental Panel on Climate Change) (2007). Impacts, Adaptation and Vulnerability. Contribution of Working Group II to the Third Assessment Report of the IPCC. In M. L. Parry, O. F. Canziani, P. J. van der Lindel, \& C. E. Hanson (Eds.), Summary for Policy Makers (Vol. 14, pp. 369-383) Cambridge University Press.

Jonathan, B. E., Gideon, A. U., \& Julius, A. (2009). An Assessment of Water Supply Potential for Crop Production: Comparative Study of River Basins Under the Jurisdiction of Two River Basin Development Authority Areas Located in Different Ecological Zones of Nigeria. Journal of Meteorology and Climate Science, 7, 1.

Knorr, W. (2009) Is the Airborne Fraction of Anthropogenic $\mathrm{CO}_{2}$ Emissions Increasing? 
Geophysical Research Letters, 36, Article ID: L21710. https://doi.org/10.1029/2009GL040613

Matsui, T., \& Pielke Sr., R. A. (2006). Measurement-Based Estimation of the Spatial Gradient of Aerosol Radiative Forcing. Geophysical Research Letter, 33, Article ID: L11813. https://doi.org/10.1029/2006GL025974

Medugu, N. I. (2009). Nigeria: The Effects of Climate Change in Nigeria. http://allafrica.com/stories/200910010424.html

Nigeria Environmental Study/Action Team (NEST) (2003). Climate Change in Nigeria. A Communication Guide for Reporters and Educators (pp. 5-16). Nigeria Environmental Study/Action Team.

Nigeria Meteorological Agency (NIMET) (2011). Nigeria: Climate Review Bulletin 2010: NMA Abuja.

Obatolu, C. R., Fashina, A. B., \& Olaiya, A. O. (2003). Effects of Climate Change on Cocoa Production in Nigeria. Proceeding of African Crop Science Conference Lagos, Nigeria (pp. 957-959).

Odjugo, P. (2010). General Overview of Climate Change Impacts in Nigeria. Journal of Human Ecology, 29, 47-55. https://doi.org/10.1080/09709274.2010.11906248

Oyedele, J. O. (2007). Enhancing the sustainability of cocoa growing in Nigeria. In A. Bamidele, A. S. Bamire, K. Ayodeji, \& F. Oluwole (Eds.), 2007 ICCO roundtable congress on sustainable World cocoa Economy at Accra, Ghana, 3rd-6th October 2007, ResearchGate.

Pouliotte, J., Smit, B., \& Westerhoff, L. (2009). Adaptation and Development: Livelihood and Climate Change in Subarnadad, Bangladesh. Climate Change and Development, 1, 31-46. https://doi.org/10.3763/cdev.2009.0001

Tanner, T., \& Mitchell, T. (2008). Entrenchment or Enhancement: Could Climate Change Adaptation Help to Reduce Chronic Poverty? Institute of Development Studies Bulletin, 39, 6-15. https://doi.org/10.1111/j.1759-5436.2008.tb00471.x

Wilcox, M. D., \& Abbott, P. C. (2004). Market Power and Structural Adjustment: The Case of West African Cocoa Market Liberalization. In EconsPapers, American Agricultural Economics Association Annual Meetings (pp. 1-4). https://ageconsearch.umn.edu/record/20084/files/sp04wi05.pdf 